\title{
The Use of Task-Based Activities to Improve Listening and Speaking Skills in EFL Context
}

\author{
Arif Sarıçoban \\ Hacettepe University, Ankara, Turkey
}

\author{
Leyla Karakurt \\ Baskent University, Ankara, Turkey
}

\begin{abstract}
The aim of this study was to improve EFL learners' English listening and speaking skills at a State University in Turkey, School of Foreign Languages, Department of Basic English B1 and B1+ groups through task-based activities. The participants were 56 in total, studying in the academic year of 2014-2015 Spring Fall. The instruments used for collecting data were 16 lesson plans and the speaking and listening quiz results as post-tests. The data were statistically analyzed by mean, max, and min values of the scores. Teaching process and the lesson plans were recorded by researcher then presented in essay form. After the implementation and the post-tests, the participants' opinions about the task were collected as an interview. The results of the study showed that B1 groups did not get significant results from listening test and get nearly significant scores from speaking test while the listening and speaking results of B1+ groups through task-based learning after the implementations were highly significant, which shows that their participation in the task-based activities in the classroom reflected the results positively. Also the students' opinions about task-based learning and teaching activities were respectively positive. As a result, it can be said that task-based activities play a significant role in improving listening and speaking skills in EFL settings.
\end{abstract}

Keywords: task-based language teaching, listening, speaking, B1 and B1+ levels and CEFR

\section{Introduction}

The importance of learning a foreign language in today's world has gained an acceleration, the speed of which is more than expected due to the developments in the communication need among people all across the world. This development has been observed in our country, not only in the financial, social arena but also in education as well. Our foreign language learners should be able to communicate with others from different countries for different purposes: study, work, education, social, financial, etc. As a country that would like to be a member of the European Union, it has become a must for our citizens to speak a foreign language or two at least to communicate with the rest of the world to solve their problems. Therefore, multilingualism or plurilingualism should be attached the necessary importance in this sense.

With this purpose in mind, the ultimate aim of our educational system has greatly changed to accommodate the recent developments by Common European Framework of Reference for Languages (CEFR): learning, teaching, and assessment. It is "a framework of reference designed to provide a transparent, coherent and comprehensive basis for the elaboration of language syllabuses and curriculum guidelines, the design of

Arif Sarıçoban, associate professor, doctor, English Language Education, Hacettepe University. Leyla Karakurt, instructor, School of Foreign Languages, Baskent University. 
teaching and learning materials, and the assessment of foreign language proficiency"... at six levels: A1 and A2, $\mathrm{B} 1$ and $\mathrm{B} 2, \mathrm{C} 1$ and $\mathrm{C} 2$. It also defines three "plus" levels $(\mathrm{A} 2+, \mathrm{B} 1+, \mathrm{B} 2+)$, "...providing a basis for recognizing qualifications and thus facilitating educational mobility" for language skills such as listening, speaking, reading, writing, and the language components for grammar and vocabulary.

CEFR provides "mutual understanding, and co-operation, and overcome prejudice and discrimination" (Council of Europe, 2001, p. 2) and it is action-oriented approach "with its emphasis on using language to perform tasks, points unmistakably in the direction of task-based teaching/learning", Little (2015) states. ${ }^{2}$ "Tasks are language activities that focus on meaning" (Ellis, 2003, p. 3), whereas Nunan (2004) affirmed that "communicative tasks are pieces of classroom work in which learners attempt to comprehend, manipulate, produce, and interact in the target language" (p. 4). Nunan maintains that tasks should have a sense of completeness and should be able to stand on their own as a form of communication and learning.

Others define "task" in a different way. Prabhu (1987) defined task as an activity that makes the learners to reach an outcome with the help of given information through thinking strategies. The instructors are expected to control and organize the learning process in this learning environment. Moreover, Willis (1996) claimed that learners use language to achieve a real outcome with the help of these goal-oriented task activities. According to Willis (1996), in order to solve problem, do a puzzle, play a game, or share and compare experiences, learners use variety of target language resources they have available in the classroom setting. Long (1985) defined "task" as "a piece of work undertaken for oneself or for others, freely or some reward" (p. 89) and he continued, "tasks are things people will tell you they do if you ask them and they are not applied linguists" (p. 89). Furthermore, Skehan (1996) defines language learning tasks as activities that focus primarily on meaning. The achievement of tasks is evaluated in terms of an outcome and they have real-life language use. What is more, Nunan (1989) briefly summarizes "task" as,

A piece of classroom work which involves learners in comprehending, manipulating, producing or interacting in the target language while their attention is principally focused on meaning rather than form. The task should also have a sense of completeness, being able to stand alone as a communicative act in its own right. (p. 10)

Tasks are composed of different parts and can come in different variations. There are goals, input, procedures, roles of the participants and the setting. An instructor should plan the various task components in order to follow a successful and productive task-based learning environment. According to Nunan, there are five elements of task-based learning which are goals, input, procedures, roles and settings. Goals are the general intentions behind a learning task (Nunan, 2004, p. 41). They are the connections between the task and the larger curriculum. To develop students' confidence in speaking and to improve their writing skills are among the examples of goals. The learners must achieve any teaching task or course goals. When completing a task, learners study spoken, written, visual, and auditory data as an input. The data mentioned here can be provided by an instructor, a textbook, or other supplementary materials. Procedures, on the other hand, as stated by Nunan (2004), "specify what learners will actually do with the input that forms the point of departure for the learning task” (p. 52).

Roles are not only the parts that learners and teachers play during conducting learning tasks but also the social and professional relationships between the participants. Also, learners develop an active role and

\footnotetext{
1 See http://www.coe.int/t/dg4/linguistic/Cadre1_en.asp.

2 See http://www.unileipzig.de/actflcefr/material/Teaching\%20Learning\%20CEFR\%20Little.pdf.
} 
awareness in the learning process. By doing so, they easily adopt the task-based language classroom. Therefore, teachers modify their role according to the learners' active participation. As Breen and Candlin (1980) indicate, there are three main roles that the teacher has in the communicative classroom. Firstly, he acts as a facilitator; secondly, he is to act as a participant, and the third is to act as an observer and learner. The optimal method of teaching tasks is the teacher's duty to stabilize what they feel which is expected from the students. Richards and Rodgers (2001) define the roles of teachers as the selector and sequencer of tasks, preparing learners for tasks and consciousness-raising. Additionally, learner roles are being a group participant, monitor, risk-taker and innovator. Moreover, setting means the classroom arrangements that are defined in the task. A wide variety of settings are possible in the classroom despite the fact that there are some constraints such as class size in a real life setting (Nunan, 2004, pp. 42-71).

Under the highlight of the above discussion, the researchers have had a common sense to focus on the use of task-based activities to improve language skills, namely, listening and speaking skills of EFL B1 and B1+ preparatory class learners at a state university in our country. For this purpose, the following research questions have been formulated by the researchers:

(1) Do the task-based learning activities employed by B1 and B1+ EFL learners foster the development of

(a) Listening skills?

(b)Speaking skills?

(2) What are the opinions of B1 and B1+ EFL learners about task-based learning activities?

\section{Method}

In this study, a mix method that includes both quantitative and qualitative procedures has been utilized for the purpose of collecting and analyzing the necessary data from the participants. The study can also be defined as an action research in that one of the researchers has done the implementation of task-based activities in her B1 and B1+ level EFL classrooms.

\section{Population and Participants}

The researcher conducted in the School of Foreign Languages, Department of Basic English at a state university in Turkey during the spring semester in 2014-2015 academic year. According to the CEFR language levels, the study was administrated with the B1 and B1+ levels. The first group has 32 students who are the voluntary students attending the preparatory education before their major studies. Their passing grade is 55 . During the post-test, two of the students did not participate in the listening quiz in B1 level and the other two participants did not attend the speaking quiz. Furthermore, the departments of the students are various as follows: Psychology (2), Chemistry (4), Biology (4), Actuarial Science (3), Computer Education and Instructional Technology (2), Health Administration (2), Economics (3), Archeology (1), Machinery (1), Hydrogeology Engineering (1), History of Art (1), Physiotherapy and Rehabilitation (1), Law (1), Physics Education (1), Public Finance (1), Geological Engineering (1), Pharmacy Services (1), Social Work (1), and Tourism (1). The second group, B1+ has 24 students who attend the preparatory class as part of their compulsory education before their major studies. Their passing grade is 65 . During post-test, all of the students participated in the listening quiz whereas one of them did not attend the speaking quiz.

Moreover, most of the students in this group are from engineering departments. The majors of the students are as follows: Electrical \& Electronic Engineering (5), Mining Engineering (3), Automotive Engineering 
Programs (1), Computer Engineering (2), Chemical Engineering (2), Industrial Engineering (1), Nuclear Engineering (2), Business Administration (3), English Economics (2), Political Science and Public Administration (2), and English Medicine (1).

\section{Duration}

The study was conducted over seven weeks in, as stated above, the spring semester of the 2014-2015 academic year. The four hours of instruction each week were divided into two equal lessons as speaking and listening. Courses were carried out from the first week until the last week. The 25 minutes of post-test of listening in B1 groups took place on March 12, 2015. Their speaking quiz lasted 10 minutes which took place on March 27, 2015. For the second group, B1+, the 30 minutes of post test was implemented on March 5, 2015 and the speaking quiz lasted 10 minutes practiced on March 27, 2015.

\section{Research Instruments}

This study analyzes the use of task-based learning to improve English listening and speaking abilities. The following research instruments were performed in this study for qualitative and quantitative data collection.

Task-based learning lesson plans. Lesson plans were designed according to the objectives based on CEFR. For listening tasks, the book called Contemporary Topics-1 by Micheal Rost which provides stimulating, task-based approach that helps students develop their listening, note-taking, and discussion skills while studying relevant topics. Each unit centers on a short academic lecture with topics drawn from a range of disciplines. The lectures feature engaging instructors with live student audiences and take place in authentic lecture hall settings. The multimodal design of each lecture allows for various learning formats for DVD users, including audio or video presentations, optional subtitling, Presentation Points slide support, and pop-up Coaching Tips. For B1 group, units 1, 2, 3, and 5 were analyzed. The rest of the units except Unit- 8 were studied by B1+ group for listening task activities. With respect to the speaking tasks, the supplementary materials provided by the Curriculum Office in the school were studied. These materials were modified according to CEFR objectives and they were in line with the textbook. ${ }^{3}$

The task model follows Willis (1996) for the different phases of the task. According to Willis, there are different task phases as the "pre-task", "task-cycle", and "language focus". In the first phase, the instructor (the co-author) introduces the topic, models the task, and recalls language. In the second phase, task-cycle, she sees the students working in pairs or groups to complete tasks given by the teacher. During the applications, the instructor monitors the students and guides them. Then, the students prepare and report to the whole class while the teacher observes and gives positive feedback. The students and the teacher work together in the language focus which is followed by the students' language practice. Lesson plans were discussed and checked and feedback was provided by professionals. The lesson plans were designed to adapt the textbook materials into meaningful tasks and provide opportunities for maximum learner participation.

Listening and speaking post-tests. The post-tests were also designed by the Testing Office in the school. Each test was checked by other professionals by proof-reading. The listening quiz consisted of two parts, note-taking and while-listening. Firstly, the students were given a note-taking sheet and they listened to the lecture twice. After taking notes, they were given the questions related to the lecture. After this part, they moved on the while-listening. For the speaking test, the major focus was speaking naturally in authentic

\footnotetext{
${ }^{3}$ See http://www.coe.int/t/dg4/linguistic/Source/Framework_EN.pdf.
} 
situations. During the test, there were two raters two students as pairs in each session. The test was divided into three parts. In the first part, the participants were expected to introduce themselves according to the questions which the examiner asked to get the students to familiarize with the exam. Students were not graded for this part. This part took total of two minutes. For the second part which was Task-1, there were individual opinion questions. The task was expected to last about two minutes for each student. The examiner asked one opinion question written on the task sheet to each student respectively. There was no interruption during the talking process. Before the student starts talking, s/he was giving at most 30 seconds to think about the question. The Task-2 was a pair-discussion question session. It was expected to last four minutes for each pair of students. They took part in a discussion, expressed their opinions, agreement, and disagreement in the given roles, justified their ideas and exchanged information. Before discussion questions, the students were given one minute to organize their ideas. In the evaluation of a speaking quiz, the students were graded according to a rubric as follows:

Table 1

\section{Speaking Exam Rubric}

Fluency, Coherence, and Task Fulfillment (35 pts)

To what extend does the student...

- organize ideas logically?

- respond to the task sufficiently?

- express and justify opinions?

- develop the task by providing responses consistent with the given role?

- discuss issues without long pauses and repetition of some words?

Grammatical Range and Accuracy (20 pts)

To what extend does the student...

- use a mix of simple and complex structures accurately?

- $\quad$ use grammatical structures correctly to make meaning clear?

Lexical Resource (20 pts)

To what extend does the student...

- use a wide range of vocabulary to discuss topics?

- use vocabulary effectively and appropriately?

Delivery and Style (15 pts)

To what extend does the student...

- $\quad$ speak loudly and clearly?

- use facial expressions and body language effectively?

- participate, initiate, and close conversations consistent with the given tasks?

Pronunciation (10 pts)

To what extend does the student pay attention to...

- individual sounds?

- word stress?

- sentence stress?

- intonation?

- intelligibility?

Interview. After the classes finished and the post-tests were implemented, the students in the both groups were divided according to their exam results as high-mid and low. From each level, two students were selected and they were given three interview questions. The interview questions were as follows:

(1) Do you believe that the speaking tasks which we studied in the classroom helped you to improve your communication skills in English? Why/Why not?

(a) In which activity did you enjoy most and feel relaxed, comfortable?

- individual work;

- pair work discussion;

- group-work discussion, and/or; 
- whole-class discussion.

(2) Can you say that the listening task activities helped you to improve your listening comprehension skills in English? Why/why not?

(a) In which activity did you enjoy most and feel relaxed, comfortable?

- listening for the main ideas/details?

- talk about the topic?

- take the unit test?

(3) Do you think that task activities should be applied in the classroom to teach listening and speaking skills in English? Why/why not?

According to these questions, the learner ideas were gathered for evaluation.

\section{Data Collection Design and Procedure}

The first step introduced the purpose of the study, method, activities, and assessment of the students. The lessons applied task-based learning and were taught to the students over a period of seven weeks. The post-test was given at the end of the quarter. Afterwards, the learner interviews were collected. Finally, the data was analyzed quantitatively and qualitatively. The reports were kept separately for each group in terms of listening and speaking tasks for seven weeks. The first two weeks' reports were explained as an example as follows. In the other five weeks, the same procedure was followed in line with the related units and the tasks.

\section{The Study - Weekly Reports}

\section{Week 1 and 2}

\section{* B1 - Listening}

The listening task of the first week was based on the topic "Psychology - Happiness", Contemporary Topics-1, Unit-1. In this unit, students discussed the topic of happiness. The lecture focused on the features of positive psychology and what research by positive psychologists has revealed about the characteristics of happy people. Following the warm-up activity, students listened to the vocabulary items included in the lecture to engage with the terminology of the topic. They studied the words and the phrases by completing the follow-up matching activity. Next, they considered the statements about happiness before listening to the unit lecture on happiness. Then they listened to the lecture $(7 \mathrm{~min} 14 \mathrm{~s})$ twice and after that, they checked main ideas mentioned in the lecture (Listen for the Main Ideas exercise) and answered true/false questions about the details (Listen for Details exercise). Following the lecture listening, there was another listening task based on the lecture: Talk About the Topic. In the track, four speakers-Mia, Manny, Hannah, and River discussed the lecture. The students completed the activity on their books. Part A focused on matching these speakers with comments or ideas from the discussion. In Part B, the learners worked on these discussion strategies:

Agreeing: "Yeah, I know what you mean".

Disagreeing: "Really? I don't think so".

For Part C, students were encouraged to use the discussion strategies they had learned. They used phrases from the discussion or they came up with their own. After that, the students were given the Take the Unit Test activity which includes 10 test items with choices lacking the questions. The lecturer played the lecture again just before giving the test. The students answered standard test questions about the content of the lecture. The test covered the following: how psychologists measure happiness, the characteristics of happy people, and exercises that people can do to feel happier. 


\section{* B1 - Speaking}

Based on the same topic with Contemporary Topics-1, Unit-1: Happiness, learners were engaged with the two speaking tasks (Task-1: 45', Task-2: 30'). The first task was a discussion. The task type and format was based on expressing agreement/disagreement, turn-taking (initiating and responding appropriately), sustaining on interaction, collaborating in the exchange of the information. The interaction pattern was two-way and three-way. The focus was to make the students use the expressions of agreement such as "uh-huh", "right", "yes!", "I agree", "exactly!", and "no doubt!". For task-1, the learners were divided into groups of three or four. They were asked to discuss one or more of the following topics by using the discussion strategies to keep the conversation going:

(1) Do you think a person can learn to be happier? Why or why not?

(2) What can an unhappy person do to become happier?

(3) What are the most important requirements for being a happy person?

After that, the learners were demonstrated a photo of a famous lady and they were told that they are required to come up with at least three suggestions for making such an unhappy person happy. At the end of their discussion, they were asked to share their suggestions with their friends. The next task for speaking was a class survey. Task type and format was based on responding to questions and expanding on responses, giving brief reasons for opinions. The interaction pattern was held in two-way. First, they were asked to carry out a class survey with at least three people. Survey questions included "what makes you happy most? Why?", and "what makes you unhappy most? Why?". At the end of the survey, they were asked to report their findings to the rest of the class and found out the most interesting things that make people happy or unhappy.

$* \mathrm{B1}^{+}-$Listening

The first listening task was based on Contemporary Topics-1, Unit-6: "Technology - Robots". In this unit, students learned about the history of robots and other machines and the lecture provided a basic definition of the term robot. It also provided a history of robots with an overview of the main types of robots used today. After the warm-up activity, the learners listened to the vocabulary items before studying the words of related topic. They studied the words and the phrases by completing the follow-up matching activity. Next, they considered what they know about robots before listening to the lecture on robots ( $5 \min 56 \mathrm{~s}$ ) two times. For the Listen for Main Ideas activity, they numbered the pictures based on the order in which they were mentioned in the lecture and answered multiple-choice questions about details in Listen for Details part. After listening to the lecture, there was another listening activity, Talk About the Topic in which four speakers-Alana, Rob, Molly, and Ayman — discussed the lecture. Part A focused on matching these speakers with ideas from the discussion. In Part B, the class worked on these discussion strategies:

Offering a fact or example: "And we learned that a robot has to have senses-you know, like it can feel, like even smell, or see...".

Trying to reach a consensus: "So, anything else?...".

For Part C, students were encouraged to use the discussion strategies they have learned. They used phrases from the student discussion or came up with their own. Following that listening task, the students were given the Take the Unit Test activity which includes 10 test items with choices lacking the questions. The lecturer played the lecture again just before giving the test. The students answered standard test questions about the content of the lecture. The test covered the following: the definition of robot, the history of robots, what modern robots need to do, and how robots are used. 


\section{* $\mathbf{B 1}^{+}$- Speaking}

Based on the same topic with Contemporary Topics-1, Unit-6: "Technology - Robots", the learners were taken part in a discussion and expressed their opinions in an organized way with the help of two tasks (Task-1: 25', Task-2: 30'). The first task was a picture dictation. It was based on an individual comprehension. In the lead-in activity, the instructor told the students that they are going to draw a picture of a robot listening to her instructions:

- Draw a rectangle at the top;

- In the rectangle draw a simple square near the top right hand corner and a small square in the top left hand corner;

- Under the two squares in the center draw a long thin rectangle, this is the face of the robot!...

The instructor continued until the drawing of the robot is completed. She asked one of the learners to share his/her drawing with the rest of the class. She also asked them to give a name to the robot as a whole class. Next, they proceeded to the first task which was based on "brainstorming". They were responsible for generating ideas on a given topic in a limited amount of time. The interaction pattern of this task was two-way. The instructor asked the learners to work in pairs and make a list of the jobs they think that robots can do. She then asked them to prioritize their lists according to their needs and interests assuming that they had a personal robot and compare their lists with the rest of the class. Next, they were given a discussion strategy to follow and informed:

By offering a fact or example, you can support your opinion and add new information on a topic. This can make the topic more understandable and more memorable. Personal experiences ("in my experience..."), observations ("I've noticed..."), and media ("I just read this article in the Times...") are a few ways you can begin.

Then, they were divided into groups of four and were demonstrated the trailer of the movie "I, Robot" to arouse the curiosity about robot movies. They were asked to discuss the questions below:

- What movies have you seen with robots in?

- Do you like movies with robots? Why/why not?

- What are the abilities of the robots in movies?

- Do you think that robots will ever exist?

- Do you think that in the future robots will become a part of our lives?

- Do you think robots can be good companions for people? Why or why not?

After the learners discussed the questions in groups, they continued with the class-discussion activity (Task-2) which is highly collaborative and individual structured turn. The instructor divided the learners into groups of four and told them to assume that they were working for a robot deign company and responsible for designing the next generation of robots to be used at home. In the following, she asked them to discuss and decide on the points given below while they were designing their own robots.

- What will your robot look like?

- What will your robot be able to do?

- What senses will your robot have? In other words, can it see, feel, hear, taste, and smell?

- How much will it cost?

- What type of people will want to buy your robot?

- What brand name will you give your robot? 
They were asked to choose a spokesperson in the group to present their robot to the class. In the end, they were asked which robot they found most interesting or useful and the learners voted on the best robot as a whole class.

\section{Results and Discussion}

The data were analyzed under the highlights of the research questions. The first research question was to examine whether the use of task-based learning was effective in improving students' listening ability. The listening ability scores in the post-test were computed and converted into mean scores. The steps of the data analysis process involved determining the means and the standard deviation of each student to check whether or not the mean scores of post-test were in the same way as expected.

The second research question was to analyze whether speaking ability improved after learning through task-based activities. The rating scores of the speaking assessment forms were calculated and converted into mean scores, then checked to see whether or not the mean scores of the post-test were meaningful.

The third research question was to examine the students' opinions about the task-based learning and teaching activities. The interviews were analyzed by the researcher after the experimentation for research findings.

In conclusion, the data were shown, analyzed, and interpreted to interpret the findings of the study. In this study the interpretations and the analysis were based on classroom participation and post-test scores. As for the interpretations of each level, the passing (achievement) grade that has been determined by the university senate for the school of foreign languages has been taken into account by the researchers (55/100 for B1 and 65/100 for B1+ level for listening skills).

Do the task-based learning activities employed by B1 and B1+EFL learners foster the development of (a) listening skills?

To answer this research question, the mean scores of the B1 and B1+ learners' listening ability on post-test were taken.

Table 2

The Scores of Listening Test

\begin{tabular}{lll}
\hline B1 Listening & & Min \\
Mean & Max & 0 \\
54,6875 & 80 & \\
\hline B1+ Listening & & 55 \\
\hline 70,625 & 100 & \\
\hline
\end{tabular}

The mean score of the participants in B1 groups can be said as insignificant (see Table 2) since the passing grade for B1 level listening skills is at least 55/100. As seen in Table 2, the mean score was below that passing score. Although two of the participants did not take the test, the minimum score was not higher than 30 points. The maximum score in the listening quiz was achieved by two students ( 80 points).

As to the mean scores of the participants in $\mathrm{B} 1+$ groups, it can be speculated that the results indicate a significant process in the application of task-based learning activities at this level. When the mean scores were taken into consideration, it was above 70,625 which was higher than 65 , a passing grade for B1+ level EFL participants in the study. Moreover, the minimum score was 55 and the maximum score was 100 . 


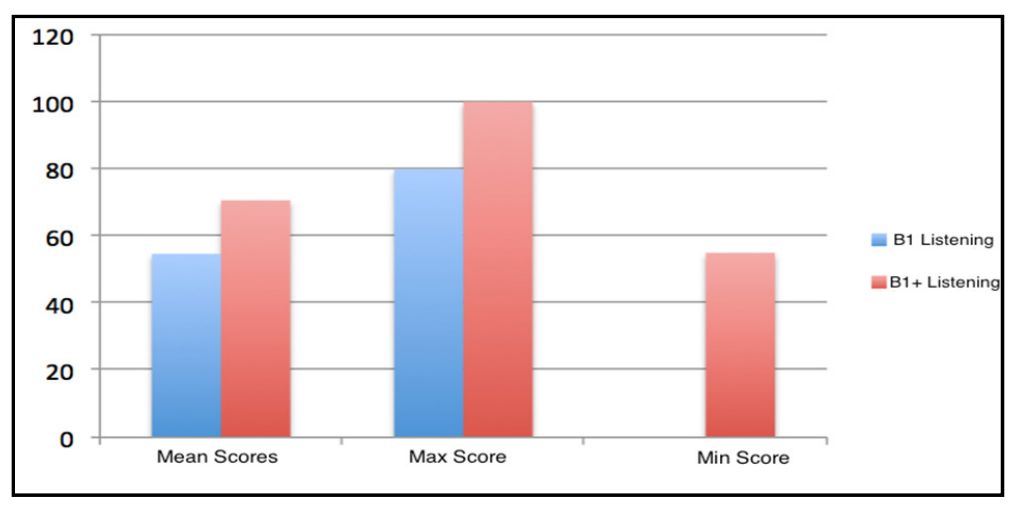

Figure 1. Listening results of B1 \& B1+ groups.

When we take a look at the scores of listening test for B1 and B1+ comparatively, there is a significant difference in the mean scores of both groups. The same difference is also valid for minimum and maximum scores.

Do the task-based learning activities employed by B1 and B1+EFL learners foster the development of (b) speaking skills?

Table 3

The Scores of Speaking Test

\begin{tabular}{lll}
\hline B1 Listening & & \\
\hline Mean & Max & Min \\
57,656 & 90 & 0 \\
\hline B1+ Listening & & \\
\hline 72,9167 & 100 & 0 \\
\hline
\end{tabular}

The mean score of speaking test for B1 level was can be considered as significant enough because the group's scores were a little higher than the passing score which was 55. The maximum score for this group was 90, while the minimum score was 0 . However, four students did not participate in the quiz. Other than these students, the minimum score was not higher than 50 .

The mean score of speaking test for B1+ level was very significant because the scores of the students were higher than the passing grade which was 65 for this group. The maximum score was 100 and the minimum score was 0 because one student did not participate in the exam. However, the minimum score was not higher than 55 except for the ones who missed the quiz.

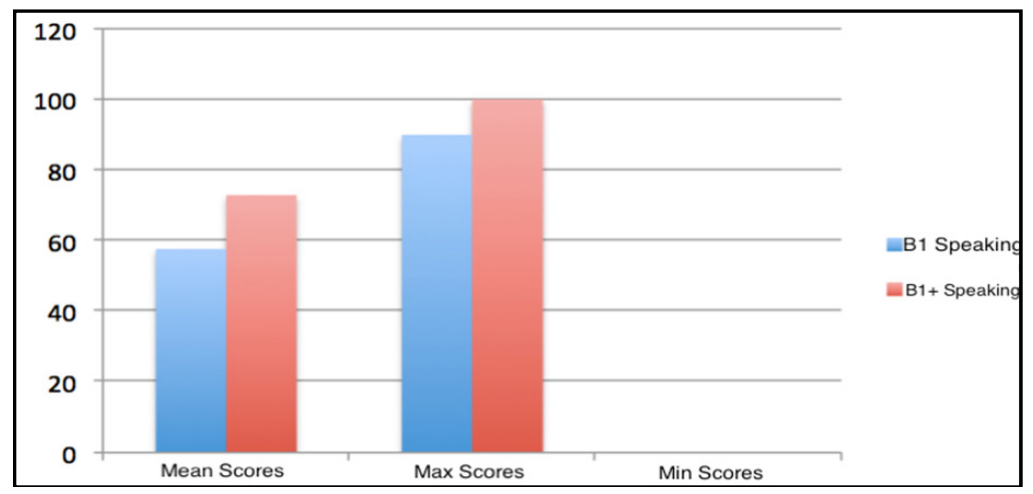

Figure 2. Speaking Results of B1 \& B1+ Groups. 
When we take a look at the scores of speaking test for B1 and B1+ comparatively, there is a significant difference in the mean scores of both groups. The same difference is also valid for maximum scores.

What are the opinions of $B 1$ and B1+EFL learners about task-based learning activities?

For the third research question, a randomly selected of $12(\mathrm{n}=6$ for B1 and $\mathrm{n}=6$ for B1+) participants were called for the interview. The participants were selected according to the high, mid, and low values of the test results.

Table 4

Students' Opinions About Task-Based Learning and Teaching Activities

Speaking B1 B1+

(1) Do you believe that the speaking tasks which we studied in the classroom helped you to improve your communication skills in English? Why/Why not?

- In which activity did you Four or

Four of six students believe that the speaking Five of six participants believe that the speaking tasks which they studied in the classroom helped tasks which they studied in the classroom helped them to improve their communication skills in them to improve their communication skills in English because the classroom environment English with the help of error correction by the provides them speaking tasks and helps them to instructor, by studying interesting subjects and opinion sharing, by gaining the ability of making sentences. However, one of the enjoy most and feel relaxed, participants believes they are not enough comfortable?

-Individual works;

-Pair-work discussion;

-Group-work discussion;

-Whole-class discussion. because there is a time limitation and the population problem in the classrooms. practice English speaking in groups. The topics were enjoying to them and they learnt new vocabulary items. However, two participants believe that speaking tasks improved their English but not much because of the population There were a variety of answers for the types of the discussion. Some of the students activities that they enjoyed and feel relaxed, comfortable.

immediately turn their native tongue. Lastly, the participants enjoyed most in pair-work and group-work discussions.

\begin{tabular}{lll}
\hline Listening & $\mathrm{B} 1$ & $\mathrm{~B} 1+$ \\
\hline
\end{tabular}

(2) Can you say that the Five of six students believe that the listening task activities helped them to improve their listening task activities helped listening comprehension skills in English but you to improve your listening one of them stated that it should be continuous comprehension skills in English? Why/why not?

- In which activity did you process and the one who thinks negatively stated that there is a problem with the comprehension process. "If you don't know some words, you enjoy most and feel relaxed, cannot understand what was told" and the other comfortable?

-Listen for the main ideas/details; -Talk about the topic; - Take the unit test. one said that it depended on the text difficulty. With respect to the activities implemented in the classroom, one of the participants enjoyed most in Take the unit test, the other four are in favor of Listen for the main ideas because there are more vocabulary items in that activity.

\begin{tabular}{ll}
\hline Interview & $\mathrm{B} 1$ \\
\hline
\end{tabular}

They believe that task-based activities should be applied in the classroom to teach listening and speaking skills in English because the learning process takes place most effectively in the

(3) Do you think that task-based activities should be classroom environment and the learners should applied in the classroom to teach listening and speaking skills in English? Why/ why not? engage in these activities so that everyone has an eager to involve. They say with the help of task-based activities, their pronunciation and comprehension skills are improved. One of the participants also states that these activities should be organized well to attract all of the students.
$\mathrm{B} 1+$

Except for one participant, the students answered this question positively because there were note-taking and while-listening activities in teaching listening process and that hearing a native speaker was an opportunity for them, so they improved comprehension skills. They also believe that listening helped improving pronunciation skills. The one that does not agree with the idea stated that it partly helped because some the activities and the topics were not interesting enough.

Among the listening activities, four participants enjoyed mostly in Listen for the main ideas because of the note-taking process. One of the participants enjoyed in Talk about the topic and the other one was in favor of Take the unit test. B1+

They all think that especially for speaking, task-based activities should be applied in the classroom to teach listening and speaking skills in English because task-based activities provide active involvement in the learning process and engage learners to do exercises constantly in the classroom environment. 
A careful analysis of Table 4 indicates that speaking and listening tasks which the participants studied in the classroom helped them to improve their communication skills in English because they say the instructor helped them to correct their mistakes in the learning process. However, some of them stated that these tasks should be implemented more in the classroom environment, and the topics should be interesting enough for the active participation.

Throughout the learning process, the students were generally motivated for the listening and speaking tasks given by the instructor. They mostly worked in pairs and as a group. During the course procedure, the learners helped each other and engaged with the activities. Nevertheless, for both group, the eager to speak in English was not obvious enough because students' characteristics were significant determinants of especially their speaking motivation. For the listening classes, the students already have the comprehension skills from their previous levels of EFL instruction.

The researcher was a guider and a facilitator in the classroom environment. She wanted to improve her students' communicative competence in engaging the task-based activities. Therefore, this helped the students to feel relaxed and comfortable throughout the process. The instructor also used non-verbal semiotic elements as body language and hand gestures in the communication circle to direct the students in the comprehension of tasks.

The purpose of the study was to analyze the use of task-based learning to develop listening and speaking abilities through task-based activities in EFL context and to examine students' opinions about the use of these activities in the classroom. The data were analyzed according to the following objectives:

(1) To examine the use of task-based learning to improve listening skills of B1 and B1+ groups in EFL context;

(2) To analyze the use of task-based learning to develop speaking skills of B1 and B1+ groups in EFL context;

(3) To examine the students' opinion about task-based learning and teaching activities.

The results revealed that B1 group who involved in task-based learning did not improve their listening skills significantly, while they showed a little achievement on the speaking test. However, B1+ group developed their listening and speaking abilities significantly. The process of task-based learning allowed the students to be involved in the activities freely and with less fear of mistakes as the time passed. What is more, they gained confidence over the course of implementations. The instructor's non-threatening and welcoming teaching style created stress-free environment in the classroom and therefore the students worked cooperatively. Another factor in the success of task-based learning was that the content of the tasks was chosen appropriately and the interview results showed that they enjoyed in the activities. Most of them believe that pair-work and group-work activities helped them a lot in the learning process. Foster and Skehan (as cited in Ellis, 2003) claim "that when students were given detailed guidance they tended to prioritize content with resulting gains in complexity when they performed the task" (p. 248). The instructor built pre-task phase to make sure the students received comprehensive input and they provided the learners with opportunities to involve in the learning process. The tasks were implemented in clear steps and instructions. The effective guidelines during the pre-task helped students become more confident and relaxed to communicate in order to accomplish learning goals.

In the task-cycle phase, the learners worked together and they shared their ideas, exchanged information, and worked together as a group to solve problems. In each group, the students were mixed as weak and strong 
and the successful ones helped the others by explaining the tasks and encourage these students. Moreover, the students provided feedback by saying that they enjoyed learning language through task-based learning because they were able to communicate freely without the worries about grammar or sentence structure. The planning phase allowed the students to practice the language in the groups and they became fluent and more confident before they presented it to the class. On the report state, the majority of students felt confident to speak in front of the class while a few of others were too shy and involved in the activities in just the discussion part by drawing and miming. The researcher was a motivator in the process and observer. She provided positive feedback when needed. All these interactions helped students practice their listening and speaking skills. In the language focus phase, students were allowed to analyze and practice linguistic features. During the post-task, careful language focus let learners speak freely during the task without an interruption. This helped the learners to improve their language skills in a natural way. The practice stage made the students to make use of the language they had learned. At this point, the researcher noticed that students became more comfortable with language use. Saville-Troika (2006) states that "learners respond to linguistic input by repeating and practicing the language that they hear and when they receive reinforcement for their learning occurs" (p. 35).

\section{Conclusion and Recommendation}

In the study, the learners were able to develop their language skills over the course of the tasks. The most productive step was the report phase in which the students asked questions to each other in exchanging roles of listener and speaker. According to the learning process, the students were arduous in developing their vocabulary and grammar due to the listening and speaking practice throughout the task. Each phase of task-based learning was focused the need for students to use language authentically in real-life situations in order to achieve the completion of the task effectively. Another significant factor in this process was the stress-free class environment. This helped students to achieve the tasks. The instructor's friendly manner helped the participants feel comfortable and relaxed about their mistakes. The teacher always directed the students positively by giving suggestions and this resulted as the improvement in student product. As Rodriguez-Bonces and Rodriguez-Bonces (2010) state, "researchers believe there is less anxiety and learning is more effective if language form per se is not the priority. If task-based instruction takes place, language learning is more meaningful and natural" (p. 166). The focus of task-based learning on fostering a comfortable and natural learning environment is in harmony with the teacher manner.

Teaching procedure recorded after each task-based learning class indicated that the learners were motivated and excited by the variety and challenge of class activities. They paid attention to and completed all tasks given by the teacher. The authentic use of language in the tasks related students' daily life routines and these topics motivated them because they had the opportunity to share their opinions with their friends.

In conclusion, the study found that task-based learning was effective in developing students' listening and speaking abilities. The implementation and the structure of task-based learning allowed the participants to express themselves freely and to practice real-world language more than normal classroom environment. For a successful task-based learning classroom, the instructor should welcome, simplify, and provide positive feedback for the students. Task-based learning provided a chance to practice speaking and listening and the topics were interesting enough for learner participant. All these points show why task-based learning is effective in improving the speaking and listening abilities of the students in EFL context. 
According to the findings, task-based learning is effective in developing listening and speaking abilities of the learners of English. For this reason, the use of task-based learning should be used as an alternative way of teaching English in the sense that it helps learners to communicate through interaction in the foreign language they are learning only because one's own experiences are considered important in the classroom learning atmosphere. Thus, in the later stages they will be able to link their in-classroom learning experiences with the language use outside the classroom, the real life.

\section{References}

Bailey, K., \& Savage, L. (1994). New ways in teaching speaking. Alexandria, VA: TESOL.

Breen, M. P., \& Candlin, C. N. (1980). The essentials of a communicative curriculum in language teaching. Applied Linguistics 1(2), 89-110.

Brown, J. D., \& Rodgers, T. S. (2002). Doing second language research. Oxford: Oxford University Press.

Brumfit, C. J. (1984). Communicative methodology in language teaching. Cambridge: Cambridge University Press.

Bygate, M., Skehan, P., \& Swain, M. (2001). Researching pedagogic tasks second language learning, teaching and testing. London: Longman.

Canale, M. (1983). From communicative competence to communicative language pedagogy. In J. C. Richards and R. W. Schmidt (Eds.), Language and communication (pp. 29-44). London: Longman.

CoE Council of Europe. (2012). Education and languages, language policy. Retrieved from http://www.coe.int/t/dg4/linguistic/Cadre1_en.asp

Council of Europe. (2001). Common European framework of reference for languages: Learning, teaching, assessment. Cambridge: Cambridge University Press. Retrieved from http://www.coe.int/t/dg4/linguistic/Source/Framework_EN.pdf

Ellis, R. (2003). Task-based language learning and teaching. Oxford: Oxford University Press.

Erickson, G., \& Little, D. (2015). Learner identity, learner agency, and the assessment of language proficiency: Some reflections prompted by the common european framework of reference for languages. Annual Review of Applied Linguistics, 35, 120-139.

Foster, P., \& Skehan, P. (1999). The effect of source of planning and focus of planning on task-based performance. Language Teaching Research, 3(3), 185-214.

Frazier, L., \& Solorzano, H. (2009). Contemporary topics-1 intermediate academic listening and note-taking skills third edition. US: Pearson Education.

Johnson, K., \& Morrow, K. (Eds.). (1981). Communication in the classroom: Application and a method in communicative approach. London: Longman.

Kasap, B. (2005). The effectiveness of task-based instruction in the improvement of learners' speaking skills. Ankara: Bilking University.

Lee, J. F. (2000). Tasks and communicating in language classrooms. United States of America: McGraw Hill.

Little, D. (2014). The CEFR and language teaching/learning. In The EALTA Conference. Retrieved from http://www.unileipzig.de/actflcefr/material/Teaching\%20Learning\%20CEFR\%20Little.pdf

Long, M. H. (1985). Input and second language acquisition theory (Technical report No. 2). Honolulu: Center for Second Language Classroom Research, Social Science Research Institute, University of Hawai'i at Manoa.

Nation, I. S. P., \& Newton, J. (2009). Teaching ESL/EFL listening and speaking. New York: Routledge.

Nunan, D. (1989). Designing tasks for the communicative classroom. Cambridge: Cambridge University Press.

Nunan, D. (1991). Language teaching methodology: A textbook for teachers. New York, NY: Prentice Hall.

Nunan, D. (2003). Practice English language teaching. Singapore: Mc Graw Hill.

Nunan, D. (2004). Task-based language teaching. Cambridge, UK: Cambridge University Press.

Prabhu, N. S. (1987). Second language pedagogy. Oxford, UK: Oxford University Press.

Promruang, J. (2012). The use of task-based learning to improve English listening and speaking abilities of Mattayomsuksa 1 Students at Piboonprachasan School. Thailand: Srinakharinwirot University.

Richards, J., \& Rodgers, T. (2001). Approaches and methods in language teaching. Cambridge, UK: Cambridge University Press. Rivers, W. M. (1980). Teaching foreign language skills. Chicago: The University of Chicago Press.

Rodriguez-Bonces, M., \& Rodriguez-Bonces, J. (2010). Task-based language learning: Old approach, new style. Profile, 12(2), 166-167, 171. 
Rost, M. (2002). Teaching and researching listening. London, UK: Longman.

Saville-Troike, M. (2006). Introducing second language acquisition. Cambridge, UK: Cambridge University Press.

Skehan, P. (1996). A framework for the implementation of task-based instruction. Journal of Applied Linguistics, 17(1), $39-59$.

Underhill, N. (1987). Testing spoken language. Cambridge, UK: Cambridge University Press.

Underwood, M. (1989). Teaching listening. London: Longman.

Ur, P. (1996). A course in language teaching. Cambridge: Cambridge University Press.

Valette, M. (1977). Modern language testing. New York: Harcourt Brace.

Willis, J. (1996). A flexible framework for task-based learning. Oxford, UK: Addison Wesley Longman. 